\title{
Predicative constituents
}

Predicative constituents are linguistic units which form a part of the predicate, or the whole predicate. Roughly speaking, a predicate is the function which is generally held by a verb in indo-european languages; nevertheless the predicate is not necessarily a verb. In ancient Greek, the predicate of a main clause can be a finite verb form, but also a noun phrase, with or without a copula. Every part of speech can be used as a predicate, and even several clauses in case of double predications.

Predicative constituents are linguistic units which form a part of the predicate, or constitute the whole predicate. Though the linguistic definition of predicates is much debated, it can be said, as a first approach of the notion, that a predicate is the function which is generally held by a verb in indo-european languages; nevertheless the predicate is not necessarily a verb. In ancient Greek, the predicate of a main clause can be a finite verb form, but also a noun phrase, with or without a copula. Almost every part of speech can be used as a predicate, and even several clauses in case of double predications.

The notion of predicate came from logic to linguistics, through a long history, since it dates back to Stoics and to Aristotle and was elaborated by logicians until now. The commonly held view is that the term predicate has several definitions: it is polysemic and linguists use different definitions of the predicate, depending partly on the linguistic level studied (a syntactic, semantic or pragmatic one), and mostly on the theoretical approach adopted (see Forsgren, Jonasson and Kronning 1998, and Merle et alii 2008 for an overview of the different meanings). The common ground of the different definitions is that the predicate is the syntactic center of the clause and that it specifies a relation or a property between the linguistic units of the clause, whether the linguistic units are defined on a syntactic level (arguments of the predicate), on a semantic level (semantic units), or on a pragmatic level (division between theme and rheme). According to the linguistic models, the predicate specifies a relation between two elements (including itself) or between several elements.

\section{Verbal constituents}

Prototypically, the predicate is expressed by a term which can bear the morphological markers of tense, aspect and mood, and possibly the markers of person. Thus, in indoeuropean languages, the most frequent predicate is the verb. In verbal sentences, the phrase 'predicative constituents' refers to linguistic units which belong to the predicative part of the clause, i.e. the verb and his modifiers such as nouns, adjectives or adverbs, if they are used as arguments of the verbal form. From a typological point of view, there are various types of predication (see Lemaréchal 2004): some languages like French have an obligatory copula, others like Russian a copula compulsory in certain syntactic contexts, others like Tagalog have several copulas, and in certain languages, for instance in Dravidian and Oceanic families, any part of speech can become a predicative constituent, without any copula (these lnguages are said omnipredicative).

In ancient Greek, a copula can be used, even in existential and equative constructions (e.g. sentences like "Socrates is wise", and "Plato is a philosopher"), i.e. in constructions where many languages use non-verbal structures. As a result, the predicative constituents of the majority of clauses in ancient Greek are based on finite verbal forms, and, when it is expressed, the copula bears the markers of person, tense, aspect and mood. However, the copula is not obligatory. Noting this situation, Benveniste (1950) claimed that the difference between verbal sentences with copula and non-verbal sentences without copula was based on the fact that non-verbal sentences were not able to express person, tense, aspect and mood, so that they were used for general and gnomic sentences. The idea was questioned and Lanérès 
(1991) proved that non-verbal sentences without copula are compatible with tense and especially with modality. As Lemaréchal (2004) points out, the question is less to understand how languages can manage without a copula, than what is the use of a copula in languages which employ it. According to Lemaréchal, the copula gives only redundant information in languages where the markers of person, tense, aspect, and mood are rarely omitted and systematically borne by verbal forms. That is the reason why Hengeveld (2008), drawing upon a different argument, which is based though on the same typological observation, admits that the sentences with copula come within non-verbal predication.

\section{Non-verbal constituents}

The phrase 'predicative constituents' can refer to linguistic units which are constitutive of the predicate; these constituents are not necessarily verbs or verbal modifiers, since the predicate can be formed out of non-verbal constituents. Almost every part of speech can be used as predicative constituents in the languages of the world: a language is all the more omnipredicative (i.e. with the largest freedom to make a predicate with any part of speech) since the markers of person, and tense, aspect and mood can be associated with any part of speech. In the languages where these markers can not be borne by any part of speech, nonverbal predication is not grammaticalized (see François and Behr, 2004). That is why in ancient Greek non-verbal constituents are generally not grammaticalized, since the morphological markers of tense, aspect and mood, and the markers of person are usually borne by the verb. However there are a few exceptions. The noun khrế('obligation'), used as a predicate since Homer, developed the morphology of a verb: even if several forms can be explained as the univerbation of the noun with the copula (the imperfect khrēn 'it had to' from khrè ên 'there was an obligation to'), there are forms which can not be explained as being based on such a univerbation with the copula (the imperfect ekhrên, with an augment before the nominal stem). As for the adverb deûro, used for orders ('here!'), it developed a morphological marker of second person plural, like an imperative (dêtte): the first utterances can be found since Homer, but the form becomes widely used in Christian prose.

Without being grammaticalized as predicates, many parts of speech can be used as predicates in ancient Greek (see Lanérès 1991 for an extensive discussion of the data in the Iliad). Predicative constituents can be noun phrases, in the nominative (Hdt. 3.53.16 turannis khrêma sphalerón 'tyranny [is] an unsteady thing'), in the genitive (Hom. Il. 4.13 níkē mèn areiphílou Meneláou 'the victory [belongs to] Menelas beloved by Ares'), or in the dative (Hom. Il. 23.736 nikē d' amophotéroisin 'and the victory [is for] both of them'). Predicative adjectives can also be used (Hom. Il. 13. 222 oú tis anè̈r nûn aítios 'noboby [is] now responsible'). Predicative constituents can also be adverbs (Hom. Il. 10.251 engúthi d'éós 'and near [is] the dawn'), or prepositional phrases (Hom. Il. 22.299 all' o mèn en teíkhei 'but he [is] within city walls').

According to Hengeveld (2008), the three major types of non verbal predication are localizing (as in Hom. Il. 22.299), property assigning (as in Homer, Iliad 4.13) and equative predications (as in Hdt. 3.53.13). These three types, and the other examples already cited are instances of predications divided into two parts, which are the non-verbal predications the most extensively studied, because they need to be differentiated with the corresponding predications with copulas. Nevertheless Lanérès (1991) points out instances of predications divided into more than two parts (e.g. Hom. Il. 24.437 soì mèn eg⿳亠丷厂 pompós 'for you, I [will be] your guide', where the predicate is the noun pompós 'guide'). There are also numerous examples of predications constituted by one part only, with nouns like khrế (or anánkhē 'necessity', moîra 'destiny', némesis 'justice', in homeric poems), or with neuter adjectives (like homeric hôs gàr ámeinon (Il. 1.217, etc.) 'for [it is] better this way'). An interesting insight on non-verbal predication is given by the utterances constituted by one part which are 
used with a directive force, in order to express orders or prohibitions, as in Aristoph. Thesm. 241 (údōr údōr ô geitones 'Water! Water, my neighbors') or Aristoph. Eccl. 695 (deûro par' hèmâs 'Here, close to us!'). In such utterances, the meaning is neither general nor gnomic, and there is no point in comparing with predications with a copula (for a discussion of directive utterances, see Denizot (2011:59-75)).

\section{Double predication}

Besides the main predication, which can be verbal or non-verbal, a secondary predication can be expressed, based on the main predication or on an argument of the main predication. As Furukawa (1996) defined it, a double predication is a phrase which is syntactically integrated into the main predication but which expresses semantically a sentential content within the main predication. The instances of double predication are sometimes very close to subordination. In ancient Greek, constructions like accusativus cum infinitivo (Pl. Euthd. 287d4 homologeîs me sophòn eînai 'you admit that I am wise') or the use of a participle agreeing with an argument of the main predication, after a verb expressing perception (e.g. Xen. An. 1.4.5.6 ékouse Kûron en Kilikiái ónta 'he learned that Cyrus was in Cilicia') are the examples of double predication which are both the most frequent and close to subordinate clauses.

There are other phrases which are farther from subordinate clauses, and also less frequent in ancient Greek: they are phrases identical to the type $a b$ urbe condita in Latin ('from the Town founded', i.e. 'from the founding of the Town', see Bolkestein 1981 for a discussion of the Latin data). Such examples exist in ancient Greek, in prepositional phrases (Hdt. 1.34.1 metà Sólōna oikhómenon lit. 'After Solon leaving' i.e. 'After Solon's leaving') or in noun phrases which are one of the main arguments of the central predication (Xen. An. 7.7.12.3 elúpei gàr autòn he khốra porthouméne lit. 'because the region ruined upset him', i.e. 'because the ruining of the region upset him', see Jones (1939) for a list of such expressions). A single noun or adjective can also be used for a double predication, according certain lexical and semantic constraints (e.g. the adjective prôtai 'first' in Lys. 2.4 prôtai dè tôn pántōn eph' hippoùs anabâsai 'first of all men mounting horses' i.e. 'they were the first of all to mount horses', or the noun katáskopoi 'inspectors' in Thuc. 8.41.1 [...] toùs Lakedaimoníous hoì êkon katáskopoi 'the Lacedaemonians who went [as] inspectors', see Wackernagel (1924:65-68) for a discussion of such a construction). 


\section{Bibliography}

Benveniste, Émile. 1950. "La phrase nominale", Bulletin de la Société de Linguistique de Paris 132/1 = 1966. Problèmes de linguistique générale I, Paris, 151-167.

Bolkestein A. Machtelt. 1981. "Factivity as a condition for an optional expression rule in Latin: The $a b$ urbe condita construction and its underlying representation", Predication and Expression in Functional Grammar, ed. by A. M. Bolkestein, H. A. combé, S. C. Dik, C. de Groot, J. Gvozdanović, A. Rijksbaron, C. Vet, London, New York, 205-233.

Denizot, Camille. 2011. Donner des ordres en grec ancien. Étude linguistique des formes de l'injonction. Rouen.

François, Jacques and Behr Irmtraud, eds. 2004. Les constituants prédicatifs et la diversité des langues. Mélanges de la Société de Linguistique de Paris n.s. 14

Furukawa, Naoyo. 1996. Grammaire de la prédication seconde. Forme, sens et contraintes. Louvain-la-Neuve.

Hengeveld, Kees. 1992. Non-verbal Predication. Theory, Typology, Diachrony. Berlin-New York.

Jones, Frank Pierce. 1939. The ab Urbe condita Construction in Greek. A study in the Classification of the Participle, Supplement to Language (Vol.15, n.1) 28, Linguistic Society of America, Baltimore.

Lanérès, Nicole. 1994. Les Formes de la phrase nominale en grec ancien, Étude sur la langue de l'Iliade. Lille.

Lemaréchal, Alain. 2004. "Typologie et théories de la prédication". Mélanges de la Société de Linguistique de Paris n.s. 14, Les constituants prédicatifs et la diversité des langues. Leuven. p. 13-28.

Lemaréchal, Alain. 2011. "Etre et avoir à travers les langues: typologie et théorisation". Lalies 31, 179-217.

Merle, Jean-Marie, ed. 2008. La prédication. (=Faits de langue 31-32). Paris.

Wackernagel, Jakob. 1924. Vorlesungen über Syntax. Basel. 